\title{
Kárpát-medencei adatok a Laciniaria plicata (Draparnaud, 1801) és az Alinda biplicata (Montagu, 1803) héjalaktanához, annak klímafüggéséhez (Mollusca, Clausiliidae)
}

\author{
DOMOKOS TAMÁS ${ }^{1}$ és DOMOKOS ÉVA² \\ ${ }^{1} \mathrm{H}-5600$ Békéscsaba, Rábay utca 11., e-mail: tamasdomokos@freemail.hu \\ ${ }^{2} \mathrm{H}-7400$ Kaposvár, Zárda utca 2. Nagyboldogasszony Iskolaközpont, email:domokosevi@gmail.com \\ Írásunk főhajtás Wagner János (1906-1948) és Wagner Mária (1938-2011) emléke előtt.
}

\begin{abstract}
Domokos, T. \& Domokos, É.: Data on the shell morphology of the Laciniaria plicata and the Alinda biplicata as well as theirs macroclimate dependence in the Carpathian Basin.

Abstract: The authors point out that the shell size of the Laciniaria plicata and the Alinda biplicata is the largest in the mountains, is the smallest in the lowland regions. The shell morphologic results be connected with climate types (Péczely 1957, 1981), but in case of vegetation zones (BORHIDI 2003) we can't speak about correlation.
\end{abstract}

Keywords: shell morphometry, biometrics, height $(\mathrm{H})$, width $(W)$, elongation $(H / W)$, interclass, frequency distribution curve, statistical calculation, climatic type, vegetation zone

\section{Bevezetés}

A puhatestűek mészvázának morfológiai leggyakrabban a faj megismerésének első lépcsőfoka. A leírásra használt jellemzők gazdag tárházából általában a következőkkel jellemeznek: magasság, szélesség/átmérő, nyúltság (magasság/ szélesség), tekercs (spira), polárszög, kanyarulatainak száma, tömege stb.

A ház formálódásával összefoglaló jelleggel THOMPSON 1917, 1942, 1959 foglalkozott. „On growth and form” című munkáiban például külön fejezetet szánt a különböző csigavonalak leírására. Ezt az utat követi többek között WAGNER 1929, STASEK 1963, DOMOKOS 1976, 1984 később SHIKov \& ZATRAVKIN 1991 és DoMOKos et al. 2014 is. PETERSEN 1921 az előbbiektöl eltérően, nem a ház/héj növekedési ütemét, hanem egy Clausilia faj házának tömege és magassága közti öszszefüggést kutatta.

Evidens, hogy a jellemzők mérése maga után vonja azok statisztikai kiértékelését: átlag, módusz, medián, terjedelem, szórás stb. meghatározását.

A morfológiai alapon tisztázott fajunk élőhelyeinek, ökológiai igényének, földrajzi elterjedésének mind teljesebb megismerése a következő lépcső. Itt kvalitatív és a rögösebb kvantitatív megoldást választhatjuk. Például LOŽEK 1964 klasszikus monográfiájában a holarktikus Pupilla muscorum élöhelyéül a nyitott/ ligettől, bozóttól mentes nedves mező és a sztyeppe közé eső, „O” jelzetű habitáttípust jelöli meg. ANT 1963 viszont -faunisztikai adatok alapján - 10 és a $22^{\circ} \mathrm{C}$-os júliusi izoterma közötti területre teszi a faj areáját. SüMEGI 1989 malakohőmérőjének kidolgozásakor e két izoterma értékhez rendeli a Pupilla muscorum letalitásának szélső értékeit, középértéküket $\left(16^{\circ} \mathrm{C}\right)$ pedig az egzisztálás optimális hőmérsékletének tekinti. Utólag jegyezzük meg, hogy a fiatal löszökhöz köthető klímaváltozás kvalitatív indikálására, már WAGNER 1977, 1981 munkáiban is találunk példát. Ő malakocönológiai indíttatású volt, hiszen ubikvista fajok mennyiségi elemzésére, bizonyos fajok dominciájára alapozta a löszrétegek klímaszakaszokra történő bontását. Megkülönböztetett hideg-száraz, hideg-nedves, meleg-száraz és melegnedves klímaszakaszokat.

A biometriát mindenekelőtt a fossziliák osztályozásánál használják, tekintettel arra, hogy lágy rész hiányában a genitáliák vizsgálatára, kemo- és molekuláris taxonómia módszerek alkalmazására nem mindig van lehetőség (SzÖŐR et al. 1992, FEHÉR et al. 2009). Természetesen, megfelelő feltételek esetén a biometria alkalmazható recens fajok, alfajok, formák, variánsok vizsgálatára, megkülönböztetésére is (LUPU 1966, PETRO 1963, DoMOKOS 1980, 1984, SHIKOV \& ZATRAVKIN 1991).

Adott recens faj esetén a statisztika az eltérö ökológiai viszonyok, elsősorban a makro- és mikroklímában megmutatkozó különbségek (DöVÉNYI et al. 1977, NAGY 1992, NAGY \& Sólymos 2002, Domokos et al. 2004) kimutatására, rekonstruálására alkalmas (LAIS 1925, GAÁL, I. 1927, ROTARIDESZ 1927,1932, AgócsY 1966, ClAUSS 1979, DOMOKOS \& FÜKÖH 1984, SólYMOS \& DoMOKos 1999, SólyMOS \& SüMEGI 1999). Mivel a klíma az állat rövidke élete alatt is jelentős ingadozást mutathat, a néhány évtizedes, félévszázados makroklíma átlagok használata - ezekhez lehet a monográfiákban, klímaatlaszokban hozzáférni - könnyen tévútra vihet.

A ponto-mediterrán centrum illir-moesiai kerület quercion farnetto járásába sorolt (BÁBA 1982) Laciniaria plicata és az Alinda biplicata alaki jellemzőire (magasság $\times$ szélesség, $\mathrm{H} \times \mathrm{W}$ ) vonatkozó, egyes szerzőknél megadott szélsőérték különbségek az eltérő klimatikus igényekkel is magyarázhatók (1. táblázat). A két faj különböző klímaigényét, klímatűrését jelzi azok areájának némileg eltérő fekvése és nagysága. A Laciniaria plicata Közép- és Kelet-Európában (januári középhőmérséklet 0 és $-15^{\circ} \mathrm{C}$, júliusi középhőmérséklet 15 és $25^{\circ} \mathrm{C}$ között); az Alinda biplicata (NoRDSIECK 2007) areája szűkebb, közel egyharmadnyi, leginkább Közép-Európában fordul elő, de felhatol Skandináviába is (januári középhőmérséklet 0 és $-10^{\circ} \mathrm{C}$, júliusi középhőmérséklet 15 és $25^{\circ} \mathrm{C}$ között) (KERNEY et al. 1983, Welter-Schultes 2012, KoleszÁr 2014).

$A$ két faj habitátigényét némileg különbözőnek tartják (Soós 1943, WALTER-SchULTES 2012 et cetera). A Laciniaria plicata kevésbé gyakori erdőkben, mivel inkább a nyitott élőhelyeket preferálja. 
E tulajdonságával függ össze sziklákra, falakra, fák oldalára történő felmászása is. A Laciniaria plicatával szemben az Alinda biplicata rendszerint az árnyékos erdei élőhelyeken tenyészik, és ritkábban jelenik meg a talajszint feletti simább felületeken. Behurcoláshoz köthető délkelet-magyarországi unikális előfordulásuk részben a gyűjtőhelyükön uralkodó mérsékelten száraz éghajlattal (KAKAS 1960), részben pedig a jelentősen fedett biotópjuk által biztosított mikroklímával magyarázható.

\section{Anyag és módszer}

Mérésekhez szükséges Laciniaria plicata $=\angle p$ illetve Alinda biplicata $=A b$ példányszámok, mintaelemszámok 10 mintahelyről egyeléses módszerrel kerültek begyűjtésre. A mintahelyek a Dunántúli-középhegység és dombság, a Tiszántúl és az Erdélyi-középhegység területén találhatók (1. ábra $-A z$ 1. és 10. minta légvonalban megközelítően 340 km-re van egymástól.) A mintaelemek száma és a mintázott faj rövidített neve a mintahelyek felsorolását követő gondolatjel után, illetve a táblázatban található.

\section{Mintavételi helyek (1. ábra)}

1. Bakony, Vinye, Cuha-szurdok, mészkősziklák (Magyar Természettudományi Múzeum, Mollusca gyűjtemény/MTM, dat.: 1980. 08. 14., leg.: Kovács Gy.) $-66 A b$

2. Somogyi-dombság, Gönye-tető leszakadása, Balaton-földvár, Camping út és a Petőfi utca közötti lépcsősor; juharos, gesztenyés, borostyános part ÉNYra néző rézsűje. (dat.: 2015. 06. 19., leg.: Domokos T.) -46 Lp és $48 A b$

3. Balaton egykori medre, Szántód, Kossuth u. 2., a müútról lefolyó csapadékkal táplált kerítés sövénye (dat.: 2008. 11. 28., leg.: Domokos, T.) - $37 L p$

4. Völgység, Lengyel, Anna-forrás katlanja, bükkös, magaskórós és borostyános (dat.: 2009. 11. 28., leg.: Domokos, T.) $-33 L p$

5. Középső- Mecsek, Sikonda, Nagy-mély-völgy, mészkősziklák (MTM, dat.: 2085. 07. 31., leg.: Kovács Gy.) - $37 A b$

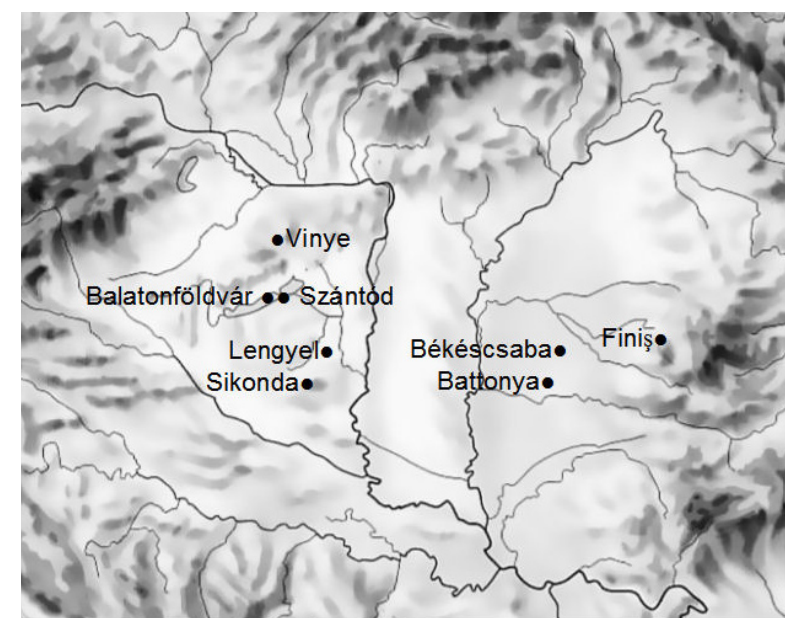

1. ábra. A gyüjtőhelyek vázlatos térképe
6. Alföld, Battonya, Damjanich J. u. 70., természet közeli gyümölcsös, fa és kerámia törmelék (dat.: 2009.11. 26., leg.: Csató A. I., Csató A. J. \& Domokos T.) $-50 L p$

7. Alföld, Békéscsaba 1., Jókai utca 11.,13., kert gally-, cserép-, téglatörmelékkel és fóliával borított része melléképület északi oldalán (dat.: 1994. 03. 29., leg.: Domokos T.) - 100 Ab

8. Alföld, Békéscsaba 2., Széchenyi u. 9., Munkácsy Mihály Múzeum bokros parkja (dat.: 1999. 10. 06., leg.: Domokos T. ) - $62 A b$

9. Alföld, Békéscsaba 3., Rábai u. 11., virágtartó betonvályú repedései (dat.: 2014. 08. 26., leg.: Domokos, T.) $-50 L p$

10. Apuseni, Munţii Codru Moma, Finiş/Várasfenes; várrom, farönk (gyertyán) és homokkő tömbök alól (dat.: 2006. 06. 04., leg.: Domokos, T. \& Domokosné Megyesi Éva) - 58 Lp

A kifejlett szájú, ép házú egyedek magassága $(\mathrm{H})$ és szélessége (W) került mérésre tolómérővel, 0,1 $\mathrm{mm}$ pontossággal. A kapott adatokból kiszámítottuk a nyúltságot $(\mathrm{H} / \mathrm{W})$, majd a kapott statisztikai adatokat 2., 3., 4., 5., 6., 7. táblázatba foglaltuk, és gyakorisági eloszlás formájában ábrázoltuk a 2., 3., 4., 5., 6., 7., 8., 9. és 10. ábrákon. A három paraméter osztályközét a következőképpen választottuk meg: $\mathrm{H}-1 \mathrm{~mm}$, W - 0,1 mm; H/W - 0,2 páros számmal indítva. Ismételt mérések átlagai $\mathrm{H}$ esetében $0,1, \mathrm{~W}$ esetében 0,02 mm-rel, H/W esetében pedig 0,02-dal tértek el egymástól.

A táblázatokban külön-külön megtaláljuk a $L p$ és $A b$ geográfiai (tengerszintfeletti magasság, kitettség), dátum, klíma (éghajlati körzetek/kategóriák/típusok PÉCZELY 1957, 1981), vegetációs öv (BORHIDI 2003), statisztikai (példányszám, minimális és maximális érték, terjedelem, átlag, módusz, szórás) adatait, jellemzőit. A táblázatokban található geográfiai adatok csak közelítő értékek, hiszen a interneten (geocaching, meteoprog, google stb.) és a szakirodalomban fellelhető számadatok igencsak eltérnek egymástól.

\section{Eredmények és diszkusszió}

1. A Laciniaria plicata-ra vonatkozó gyakorisági eloszlási görbékből (2-4. ábra) a következők olvashatók ki:

- A lengyeli és a váradfenesi biotópból származó egyedek magasságának frekvencia görbéi eklatánsan elkülönülnek az összefonódó balatonföldváriszántódi ( 2 km távolság!) és battonyai-békéscsabai biotóp görbéitől.

- A váradfenesi és a békéscsabai egyedek szélesség értékeinek eloszlása emelhető ki a többiek közül, az előbbi a nagy, az utóbbi alacsony értékei miatt.

- A magasság értékekhez hasonlóan kiemelkedik a lengyeli és a váradfenesi minta nyúltsága.

A 2. és 3. táblázatból kitűnik, hogy a Laciniaria plicata $\mathrm{H}$ és $\mathrm{W}$ szélsőértékei az 1 . táblázatban bemutatott értékeken csak Battonyán lép túl. Nevezetesen, a $\mathrm{H}$ minimális értéke itt $13,1 \mathrm{~mm}$, azaz a Soós-féle 13,5 mm-es értékénél 0,4 mm-rel kisebb. 
Az 1. táblázatban bemutatott szerzők közül, Soós Lajos sarokszámaihoz állnak legközelebb a 2. és 3. táblázatunkban látható szélsőértékek.

A Laciniaria plicata magasságok átlaga praktice 15 és $17 \mathrm{~mm}$ között ingadozik. Legkisebb érték Balatonföldváron $(14,99)$, legnagyobb pedig Váradfenesen (Finiş, Béli-hegység / Codru-Moma - 16,66) adódott. Ennél csupán néhány $0,1 \mathrm{~mm}$-rel kisebb a Völgységben található lengyeli Anna-forráshoz köthető érték $(16,39)$. Ez utóbbi helyen tapasztaltuk a $\mathrm{H}$ legnagyobb terjedelmét $(5,1 \mathrm{~mm})$ és szórását $(1,06)$ is.

A Laciniaria plicata átlagszélessége megközelítően 0,1 mm-rel tér el egymástól a hat gyűjtőhelyen. Battonyán meglepően kicsi a szórás $(0,10)$, amit a populáció izoláltságának tulajdoníthatunk. Talán a balatonföldvári és a várasfenesi mintát lehetne még kiemelni, az előbbit a legkisebb $(3,58 \mathrm{~mm})$ az utóbbi a legnagyobb (3,82 $\mathrm{mm}) \mathrm{W}$ értéke miatt.

Lengyelben és Várasfenesen jelentősebb az átlagnyúltság $(4,47$ és 4,31$)$ és a móduszok is. A lengyeli Anna-forrásnál maximális a terjedelem is (2., 3., 4. táblázat).

2. Szembetűnő, hogy az Alinda biplicata egyes lelőhelyeihez tartozó frekvencia görbéi (5-7. ábra) jobban elkülönülnek egymástól, mint a Laciniaria plicata hasonló paramétereket ábrázoló grafikonjai.

- A gyertyános-tölgyes vegetációs övbe tartozó, mérsékelten hűvös-mérsékelten nedves körzetbe tartozó sikondai biotóp magasság értékeinek frekvencia görbéje tolódik el legjobban a nagyobb értékek felé, megelőzve a szintén gyertyános-tölgyes övbe, hűvös-mérsékelten nedves körzetbe sorolt vinyei élőhely frekvencia görbéjét. Meglepő a mérsékelten meleg-száraz körzetbe sorolt három másik gyűjtőhely közül a Békéscsaba 1.-höz tartozó frekvencia görbe nagyobb értékek felé tolódása, középső helyzete, amelyet a biotóp erős fedettségével és északias expozíciójával magyarázhatunk.

- A szélesség frekvencia görbéi között Vinye szerepét nagy meglepetésre Békéscsaba 1 . veszi át, Békéscsaba 2. helyére pedig Balatonföldvár szorul kisebb értékeivel.

- Sikonda és Vinye biotópjainak nyúltság értékeit ábrázoló frekvencia görbék a magassághoz képest szerepet cserélnek.

Az 1. és 5., 6. és 7. táblázat Alinda biplicata adatait szemlélve megállapíthatjuk, hogy Soósnál, Grossunál, Kerneynél és munkatársainál, valamint Welter Schultesnél sem találunk olyan alacsony $\mathrm{H}$, illetve olyan magas $\mathrm{H}$ és $\mathrm{W}$ értékeket, mint Békéscsaba 2.on $(13,5 \times 3,3)$, illetve a mecseki Nagy-mély-völgyben (Sikonda) $(22,4 \times 4,7)$

Dolgozatunkban az Alinda biplica csupán öt helyröl (Vinye, Balatonföldvár, Sikonda, Békéscsaba 1. és 2.) reprezentált. $A z$ 5., 6. és 7 . táblázatban található statisztikákból kitűnik, a magasság átlag Békéscsaba 2. - Balatonföldvár-Békéscsaba 1. - Vinye-Sikonda, a szélesség átlag Békéscsaba 2. - BalatonföldvárVinye-Békéscsaba 1. - Sikonda, a nyúltság Balaton-
földvár-Békéscsaba 1. - Békéscsaba 2. - SikondaVinye sorrendben nő 36 (H) illetve 24 (W) \%-al. A nyúltság esetében a magasságnál talált Vinye és Sikonda sorrend szerepet cserél. Itt a növekedése csupán $10 \%$.

3. Tekintettel arra, hogy Balatonföldváron a Laciniaria plicata és az Alinda biplicata is előfordul, önkénytelenül adódik a két faj paramétereinek összehasonlítása. A 8., 9. és 10. ábrán látható gyakorisági oszlopdiagramok megközelítően természetes szóródást mutatnak, egy kis jóindulattal a Gauss-eloszlásra emlékeztetnek. A Laciniaria plicata magasság esetében csak a 14 és 16 mm-es értékek között, szélesség esetében 3,6 mm alatt, nyúltságnál $4,2 \mathrm{~mm}$ felett mutat nagyobb értékeket az Alinda biplicatánál.

Átlagokat vizsgálva (2-7. táblázat) megállapítható, hogy a magasság és a szélesség - Gordon Riley remek grafikájával összhangban (11. ábra) - az Alinda biplicata, a származtatott nyúltság pedig a Laciniaria plicata esetében ér el nagyobb értéket. A móduszok csak a magasság esetében térnek el némileg az Alinda biplicata javára. Nagyobb számértékekkel, a mérésterjedelem és a szórás tekintetében is, az Alinda biplicata rendelkezik.

\section{Konklúzió}

Ha az általunk nyert magasság és szélesség szélsőértékeket összevetjük az 1. táblázat adataival, és azokat kiegészítjük az általunk a DK-Alföldön nyert szélsőértékekkel, akkor a következő eredményre jutunk:

Laciniaria plicata: 13,1-21×3,0-4,5

Alinda biplicata: $13,5-22,4 \times 3,3-4,7$

Véleményünk szerint a Battonyán nyert $13,1 \mathrm{~mm}$ es magasság a Laciniaria plicata, a Békéscsaba 2. habitátban kapott $13,5 \times 3,3 \mathrm{~mm}$ eredmény pedig az Alinda biplicata alsó letelitási értékének felel meg.

A biometrizált karakterisztikák (magasság, szélesség, nyúltság) statisztikus kiértékelése során megállapítást nyert, hogy a Laciniaria plicata és az Alinda biplicata héjmorfológiája összefügg a gyűjtőhely földrajzi térbeli elhelyezkedésével, pozíciójával. A héj magassága és nyúltsága sík - domb - hegy irányban nő, és ettől a tendenciától csupán a szélesség értékek mutatnak itt-ott némi eltérést. Mivel a tengerszint feletti magasság változásával más éghajlati körzetbe és más vegetációs övbe találjuk a habitátokat, nem véletlen, hogy ezek a változások a héjmorfológiában is megmutatkoznak. Annak ellenére, hogy az éghajlati körzetek makroklímatikus alapon készültek, a szárazföldi puhatestüek - talaj közeli élőhelyük miatt - pedig a mikroklímához kötődnek, a makroklíma és a tanulmányozott két orsócsiga paraméterei megbízható korrelációt mutatnak. A kölcsönös megfelelést nem befolyásolja az a tény sem, hogy a gyűjtések időpontjai esetenként - a kívánalmak ellenére - jelentősen eltérnek egymástól. Ebből arra lehet következtetni, hogy a makroklíma elemeiből meghatározott éghajlati körzetek határai néhány évtized alatt számottevően nem változnak meg. 


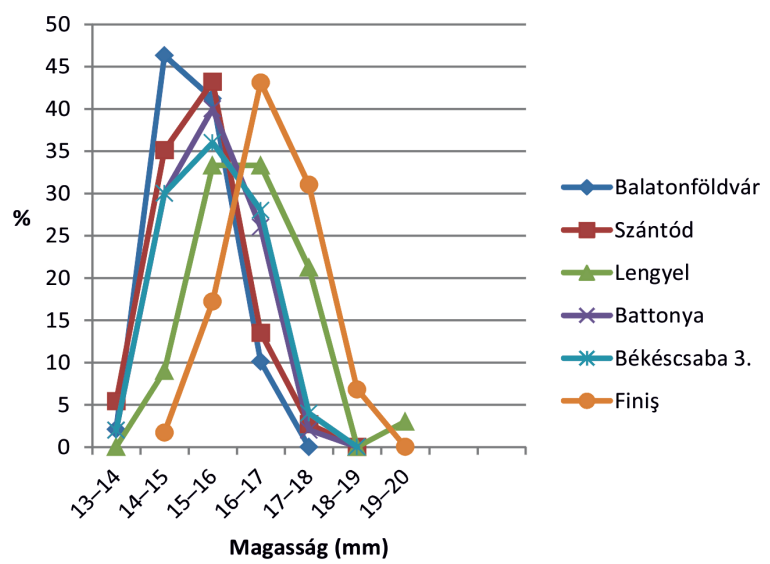

2. ábra. Laciniaria plicata magasság $(H)$ értékeinek (13-20 mm) gyakorisági eloszlása (\%) a különböző gyüjtőhelyeken

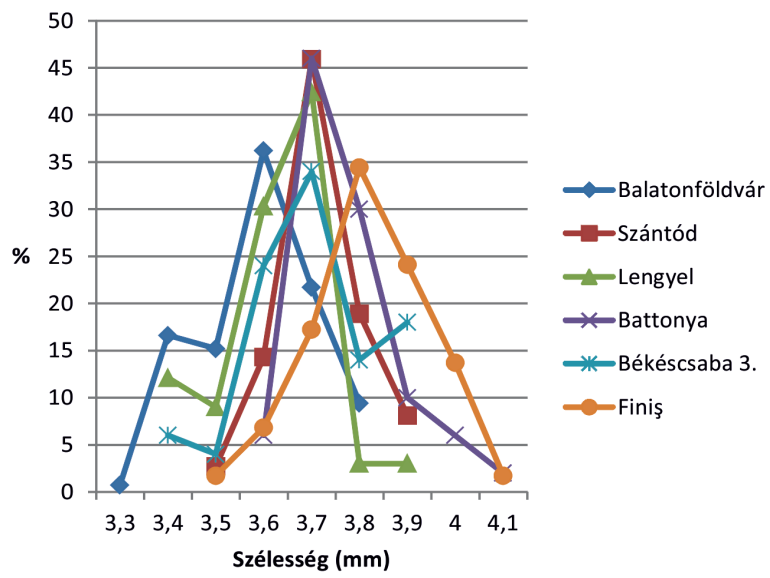

3. ábra. Különböző gyüjtőhelyekről származó Laciniaria plicata szélesség (W) értékeinek (3,3-4,1 mm) gyakorisági eloszlása (\%)

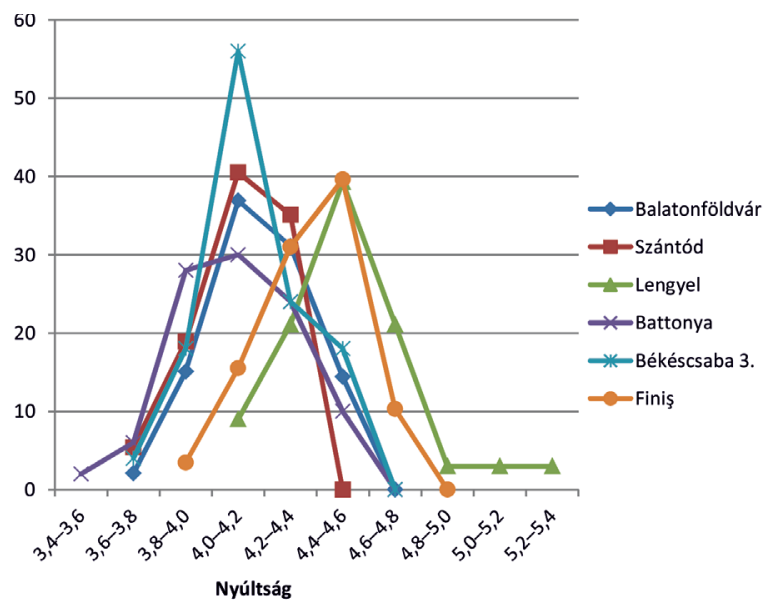

4. ábra. Laciniaria plicata nyúltság $(H / W)$ értékeinek (3,4-5,4 mm) gyakorisági eloszlása (\%) egyes gyüjtőhelyeken

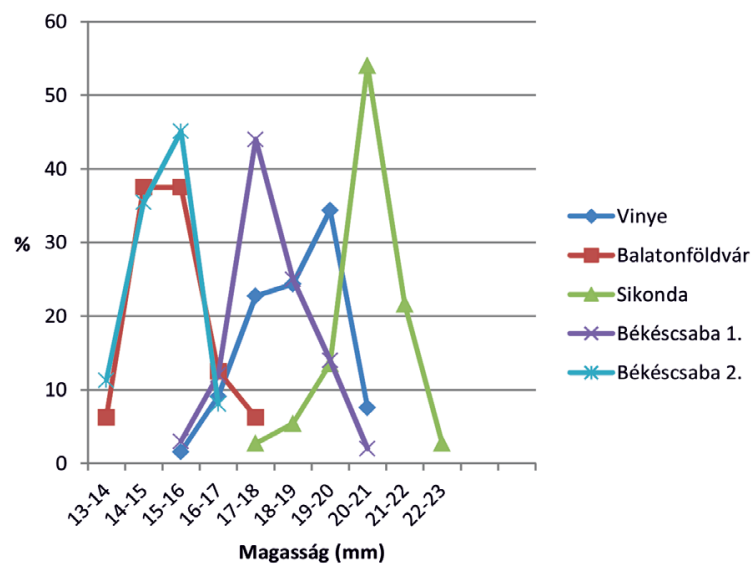

5. ábra. A különböző gyüjtőhelyekről származó Alinda biplicata magasság $(H)$ értékeinek (13-23 mm) gyakorisági eloszlása (\%)

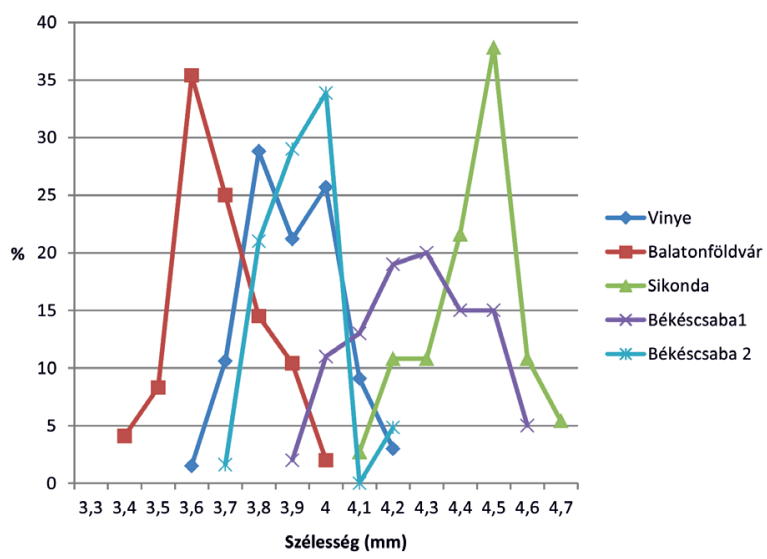

6. ábra. Alinda biplicata szélesség (W) értékeinek (3,4-4,7 mm) gyakorisági eloszlása (\%) a különböző biotópokban

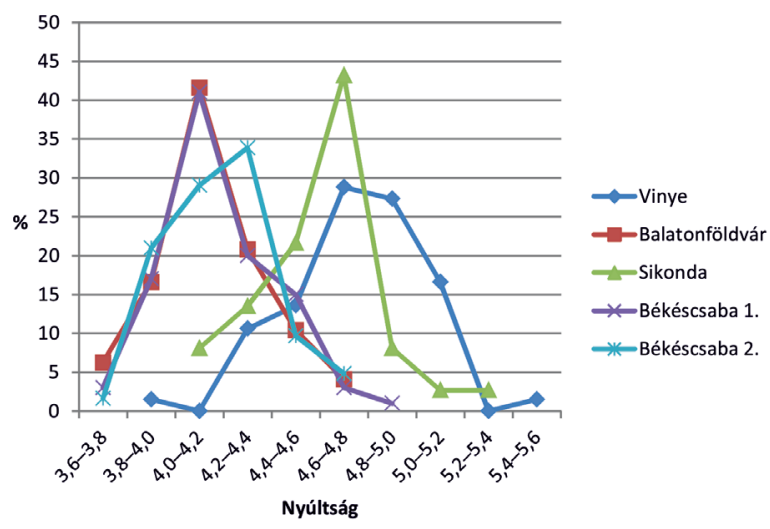

7. ábra. A különböző gyüjtőhelyekről származó Alinda biplicata nyúltság $(H / W)$ értékeinek $(3,6-5,6 \mathrm{~mm})$ gyakorisági eloszlása (\%) 


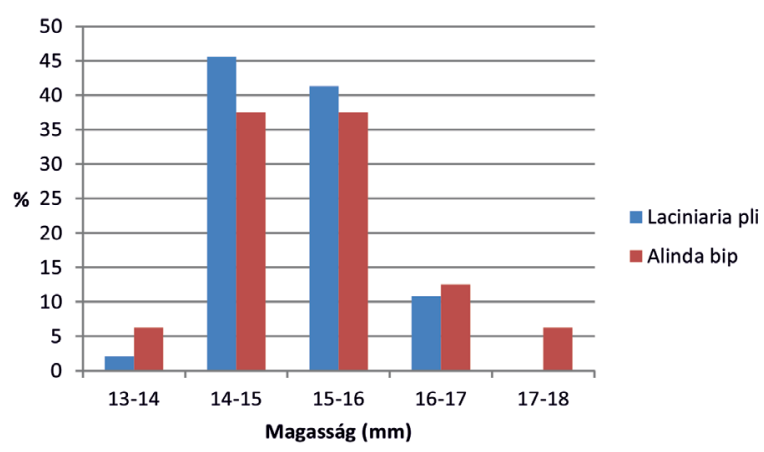

8. ábra. Az azonos biotópból (Balatonföldvár) származó Alinda biplicata és Laciniaria plicata magasság $(H)$ értékeinek (13-18 $\mathrm{mm})$ összehasonlító diagramja

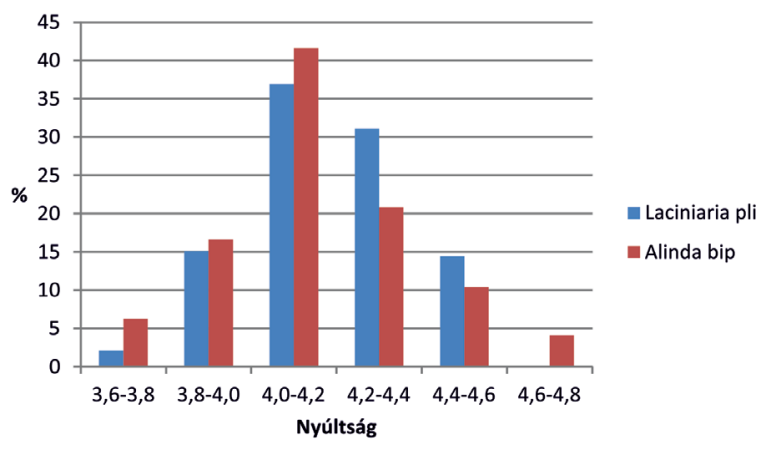

10. ábra. Az azonos biotópból (Balatonföldvár) származó Alinda biplicata és Laciniaria plicata nyúltság $(H / W)$ értékeinek $(3,6-4,8 \mathrm{~mm})$ összehasonlító diagramja

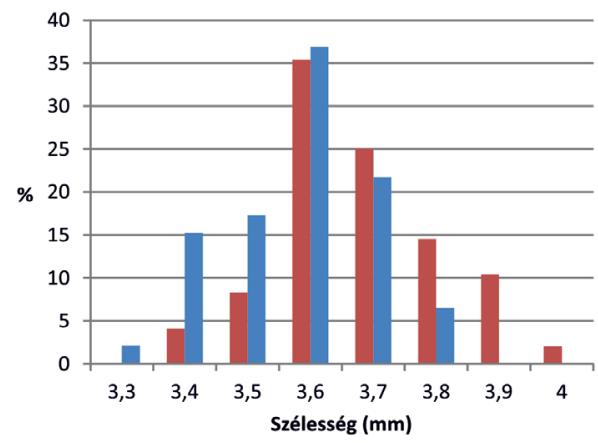

9. ábra. Az azonos biotópból (Balatonföldvár) származó Alinda biplicata és Laciniaria plicata szélesség (W) értékeinek (3,3-4,0 mm) összehasonlító diagramja
Alinda bip - Laciniaria pli
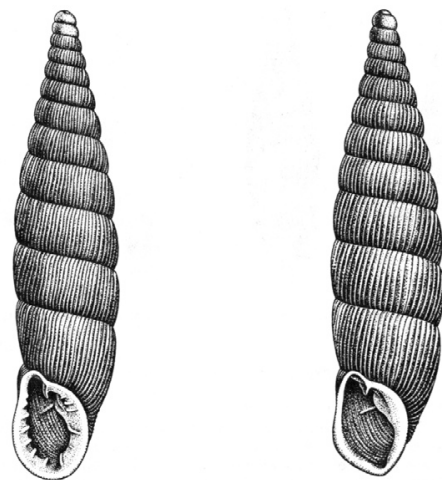

11. ábra. $18 \mathrm{~mm}$ magas Laciniaria plicata (balról) és Alinda biplicata (jobbról) Kerney et al. 1983 szerint

1. táblázat. A Laciniaria plicata $(L p)$ és az Alinda biplica $(A b)$ magasság×szélesség $(H \times W)$ szélsőértékei különböző szerzőknél

\begin{tabular}{|c|c|c|c|c|}
\hline & Soós 1943 & Grossu 1981 & Kerney et al. 1983 & Welter-Schultes 2012 \\
\hline Lp & $13,5-21 \times 3,5-4,5[1]$ & $15-19 \times 3-4[2]$ & $15-18 \times 3,3-3,6$ & $15-18 \times 3,3-3,6$ \\
\hline Ab & $15-18 \times 3,5-4[3]$ & $5-18 \times 3,5-4[4]$ & $16-18(-22) \times 3,8-4$ & $15-18 \times 3,8-4,5$ \\
\hline
\end{tabular}

[1] Soós (1943) subsp. transsylvanica, f. costata, var.biharica, var. seudostabilis, f. implicata, var.minor különböztet meg. Ezek figyelembevételével a magasság legkisebb értéke $12.5 \mathrm{~cm}$, a szélességért pedig $3.3 \mathrm{~mm}$

[2] Grossu 1981 subsp. transsylvanica, subsp. costata, subsp.biharica, f.implicata, f.minor különböztet meg, Ezek figyelembevételével a legkisebb magasság érték $12 \mathrm{~mm}$ a legnagyobb szélesség érték pedig $4,2 \mathrm{~mm}$

[3] Soós (1943) var. grandis, f. elongata, var. sordina, var carpatica, var. labiata alakokat különböztet meg. Ezek figyelembevételével a szélsőértékek: $12.0-23,5 \times 3.0-4,2$.

[4] Grossu 1981 a grandis, sordida,citrinella formát figyelembe véve a magasság szélsőértékei 12-22 mm, a legnagyobb szélességérték $5.5 \mathrm{~mm}$ 
2. táblázat. A Laciniaria plicata magasság $(H)$ értékeihez tartozó geográfiai, meteorológiai, vegetációs és statisztikai adatai a különböző gyüjtőhelyeken, különböző időpontokban

\begin{tabular}{|c|c|c|c|c|c|c|c|c|c|c|c|c|}
\hline 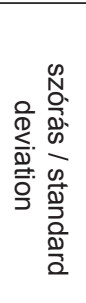 & 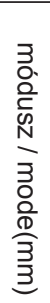 & 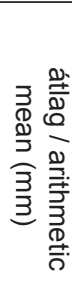 & 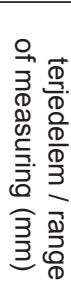 & 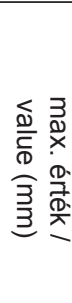 & 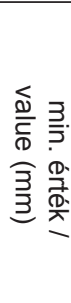 & 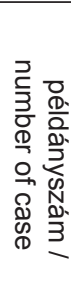 & 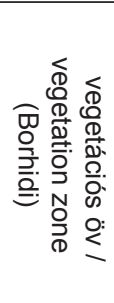 & 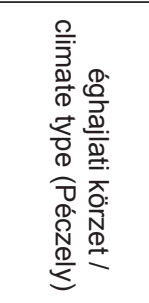 & 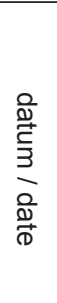 & 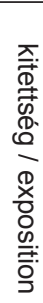 & 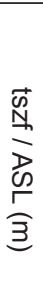 & \\
\hline 으 & $\begin{array}{l}\vec{f} \\
\vec{v}\end{array}$ & $\begin{array}{l}\overrightarrow{\vec{D}} \\
\vec{c}\end{array}$ & $\stackrel{\omega}{v}$ & $\begin{array}{l}\vec{\sigma} \\
0\end{array}$ & $\underset{\sim}{\vec{\omega}}$ & के & \multirow{3}{*}{ 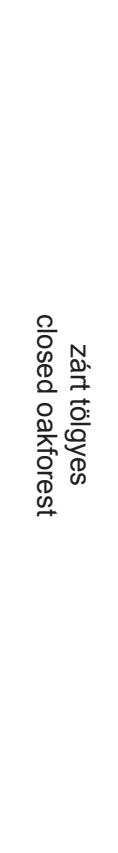 } & \multirow{2}{*}{ 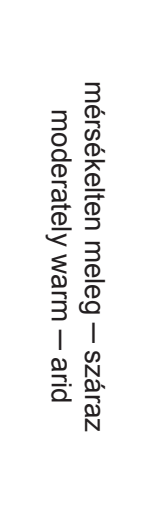 } & $\begin{array}{l}N \\
0 \\
\text { ज़ } \\
\dot{\circ} \\
\dot{0} \\
\overrightarrow{0}\end{array}$ & $\sum_{\sum}^{\text {m. }}$ & $\vec{\Xi}$ & 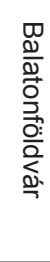 \\
\hline 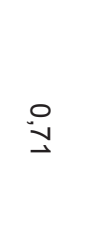 & $\begin{array}{l}\overrightarrow{\hat{T}} \\
\vec{\sigma}\end{array}$ & $\begin{array}{l}\vec{v} \\
\overrightarrow{0}\end{array}$ & $\underset{\sim}{\omega}$ & $\vec{v}$ & $\begin{array}{l}\vec{\omega} \\
\omega\end{array}$ & $\underline{v}$ & & & $\begin{array}{l}\tilde{O} \\
0 \\
\stackrel{\vec{\Delta}}{\vec{N}} \\
\dot{\tilde{N}}\end{array}$ & 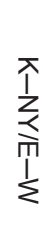 & $\vec{\circ}$ & 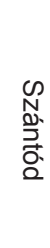 \\
\hline $\overrightarrow{8}$ & $\begin{array}{l}\vec{v} \\
\vec{v}\end{array}$ & $\begin{array}{l}\vec{\sigma} \\
\ddot{\omega}\end{array}$ & $\stackrel{G}{\longrightarrow}$ & $\begin{array}{l}\overrightarrow{0} \\
\ddot{0}\end{array}$ & $\underset{\infty}{\vec{D}}$ & $\stackrel{\omega}{\omega}$ & & 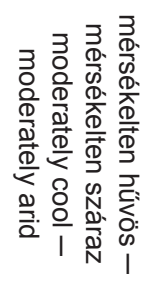 & $\begin{array}{l}\tilde{O} \\
\stackrel{0}{0} \\
\stackrel{\vec{\sim}}{\text { N }}\end{array}$ & $\frac{m}{z}$ & $\stackrel{\overrightarrow{0}}{\overrightarrow{0}}$ & 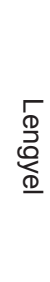 \\
\hline 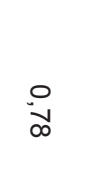 & $\begin{array}{l}\vec{\omega} \\
\vec{\omega}\end{array}$ & $\begin{array}{l}\vec{v} \\
\omega \\
\sigma\end{array}$ & $\underset{\sigma}{\omega}$ & $\vec{v}$ & $\stackrel{\vec{\omega}}{\vec{\omega}}$ & 잉 & & 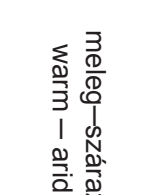 & 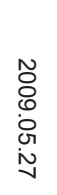 & $\frac{m}{z}$ & $\mathscr{C}$ & 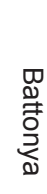 \\
\hline$\stackrel{0}{0}$ & $\begin{array}{l}\vec{\varphi} \\
\vec{\sigma}\end{array}$ & $\begin{array}{l}\vec{v} \\
\text { जे }\end{array}$ & $\underset{\omega}{\omega}$ & $\underset{D}{\vec{D}}$ & $\begin{array}{l}\vec{\omega} \\
\vec{\omega}\end{array}$ & 잉 & 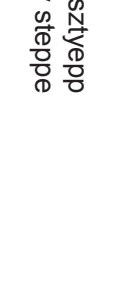 & 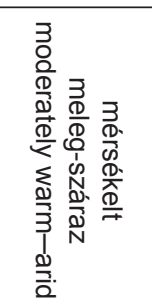 & $\begin{array}{l}\tilde{O} \\
\stackrel{0}{+} \\
\dot{0} \\
\infty \\
\tilde{N}\end{array}$ & $\stackrel{3}{3}$ & 8 & 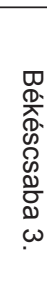 \\
\hline$\stackrel{\circ}{y}$ & $\begin{array}{l}\overrightarrow{\hat{l}} \\
\vec{v}\end{array}$ & $\begin{array}{l}\vec{\circ} \\
\stackrel{\circ}{\circ}\end{array}$ & $\underset{\omega}{\omega}$ & $\underset{\substack{\infty \\
\omega}}{\vec{\omega}}$ & $\underset{\infty}{\vec{\Phi}}$ & ભ্ & I & I & $\begin{array}{l}\text { ڤ్ } \\
\dot{0} \\
\dot{0} \\
\dot{0}\end{array}$ & $\frac{m}{z}$ & $\stackrel{\mathrm{O}}{\mathrm{O}}$ & $\frac{T}{\bar{s}}$ \\
\hline
\end{tabular}


BIPLICATA HÉJALAKTANÁHOZ, ANNAK KLÍMAFÜGGÉSÉHEZ

3. táblázat. A Laciniaria plicata szélesség $(W)$ értékeihez tartozó geográfiai, meteorológiai, vegetációs és statisztikai adatai a különböző gyüjtőhelyeken, különböző időpontokban

\begin{tabular}{|c|c|c|c|c|c|c|c|c|c|c|c|c|}
\hline$\frac{. m}{E}$ & $\frac{0}{i n}$ & ש. & 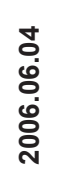 & 1 & 1 & $\stackrel{\infty}{\circ}$ & $\stackrel{\text { L }}{n}$ & $\bar{f}$ & $\stackrel{0}{\circ}$ & 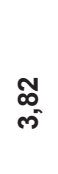 & $\stackrel{\infty}{\tilde{m}^{-}}$ & $\stackrel{N}{\circ}$ \\
\hline 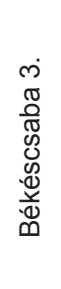 & ৪ & 之े & 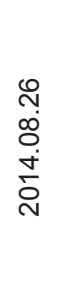 & 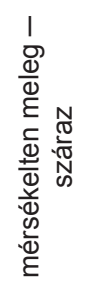 & 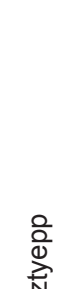 & 오 & $\stackrel{\nabla}{m}$ & $\stackrel{\sigma}{m}$ & L & $\hat{m}$ & $\hat{m}$ & $\stackrel{m}{\circ}$ \\
\hline 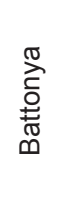 & ஜூ & ש & 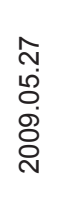 & 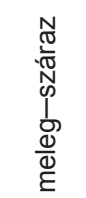 & $\frac{0}{0}$ & ८) & $\stackrel{0}{\infty}$ & F & L & $\begin{array}{l}\hat{N} \\
\hat{m}\end{array}$ & $\hat{m}$ & $\overline{0}$ \\
\hline $\begin{array}{l}\bar{\Phi} \\
\text { बे } \\
\text { Ф) }\end{array}$ & $\stackrel{\circ}{\sim}$ & שי & 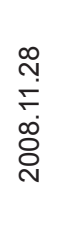 & 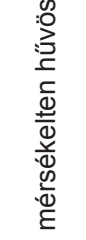 & & m & $\stackrel{\oplus}{\oplus}$ & $\stackrel{\vec{m}}{\mathrm{~m}}$ & L̊ & $\begin{array}{c}\widetilde{\infty} \\
\text { ల }\end{array}$ & $\hat{m}$ & E \\
\hline 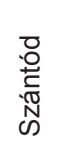 & $\stackrel{\infty}{\circ}$ & $\begin{array}{l}\sum_{1}^{1} \\
\Sigma\end{array}$ & 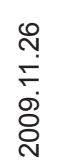 & 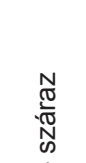 & 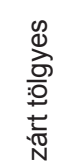 & $\hat{m}$ & $\stackrel{L}{\infty}$ & $\stackrel{\text { m}}{m}$ & $\stackrel{*}{0}$ & $\hat{m}$ & $\hat{m}$ & $\begin{array}{l}\text { \&̊ } \\
\text {. }\end{array}$ \\
\hline 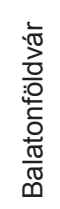 & $\Xi$ & . & 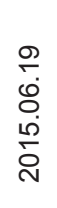 & 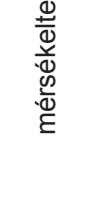 & & $\mathscr{q}$ & $\stackrel{m}{m}$ & $\stackrel{\infty}{\boldsymbol{\infty}^{-}}$ & ${ }_{0}^{0}$ & $\begin{array}{l}\infty \\
\stackrel{\infty}{\infty} \\
n^{\circ}\end{array}$ & $\stackrel{0}{\infty}$ & $\stackrel{\sim}{\leftarrow}$ \\
\hline$\stackrel{\rho}{ }$ & $\underset{\substack{\mathbb{N} \\
\underline{\Phi}}}{\widehat{E}}$ & 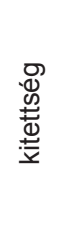 & 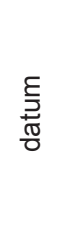 & 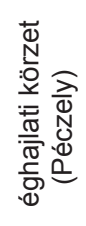 & 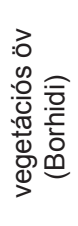 & 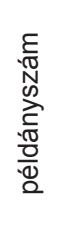 & 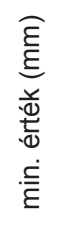 & 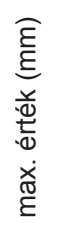 & 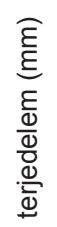 & 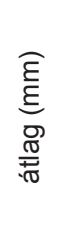 & 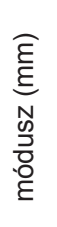 & 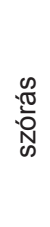 \\
\hline
\end{tabular}


4. táblázat. A Laciniaria plicata nyúltság $(H / W)$ értékeihez tartozó geográfiai, meteorológiai, vegetációs és statisztikai adatai különböző gyüjtöhelyeken, különböző időpontokban

\begin{tabular}{|c|c|c|c|c|c|c|c|c|c|c|c|c|}
\hline $\begin{array}{l}\text { Ñ } \\
\text { ON. } \\
\text { di. }\end{array}$ & 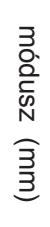 & 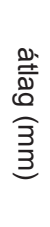 & 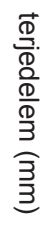 & 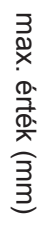 & 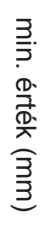 & 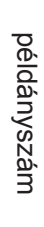 & 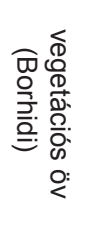 & 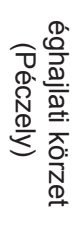 & $\begin{array}{l}\stackrel{\stackrel{9}{*}}{\vec{F}} \\
\stackrel{5}{3}\end{array}$ & 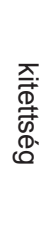 & $\frac{\substack{\mathbb{N} \\
\widehat{N}}}{\widehat{3}}$ & \\
\hline$\stackrel{\circ}{\vec{\theta}}$ & $\begin{array}{l}\vec{p} \\
\hat{i} \\
\vec{N}\end{array}$ & $\stackrel{\overrightarrow{\vec{D}}}{\vec{D}}$ & $\stackrel{0}{v}$ & $\overrightarrow{\text { जे }}$ & $\begin{array}{r}\omega \\
\infty\end{array}$ & के & & 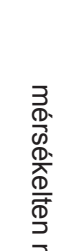 & $\begin{array}{l}\text { O } \\
\text { जे } \\
\ddot{\circ} \\
\stackrel{\circ}{\overrightarrow{0}} \\
\overrightarrow{0}\end{array}$ & $\underset{2}{2}$ & $\vec{\Xi}$ & 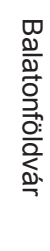 \\
\hline$\stackrel{\circ}{\vec{v}}$ & $\begin{array}{l}\stackrel{\overrightarrow{0}}{i} \\
\stackrel{+}{N}\end{array}$ & $\overrightarrow{\vec{o}^{\circ}}$ & $\stackrel{0}{v}$ & $\vec{\omega}$ & $\stackrel{\omega}{\omega}$ & $\stackrel{\omega}{v}$ & 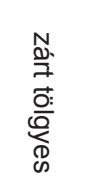 & 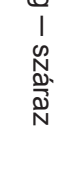 & $\begin{array}{l}\tilde{O} \\
\vdots \\
\stackrel{\vec{\nu}}{\vec{N}} \\
\text { o }\end{array}$ & $\begin{array}{l}\bar{\lambda} \\
\gtrless\end{array}$ & $\vec{\circ}$ & 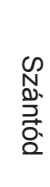 \\
\hline 品 & $\begin{array}{l}\vec{t} \\
\vec{b}\end{array}$ & $\stackrel{\vec{t}}{\vec{V}}$ & $\vec{N}$ & $\stackrel{\sim}{N}$ & $A$ & $\underset{\omega}{\omega}$ & & 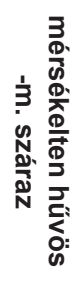 & 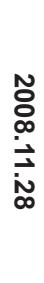 & $m$ & $\stackrel{\tilde{a}}{0}$ & 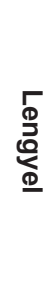 \\
\hline$\stackrel{\circ}{N}$ & $\begin{array}{l}\stackrel{\overrightarrow{0}}{i} \\
\stackrel{t}{N}\end{array}$ & $\stackrel{\vec{f}}{\dot{\phi}}$ & $\rightarrow$ & $\overrightarrow{\text { जे }}$ & $\stackrel{\omega}{\sigma}$ & 잉 & & 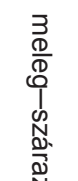 & $\begin{array}{l}\tilde{O} \\
0 \\
0 \\
\dot{0} \\
\text { iv } \\
\text { v }\end{array}$ & $\mathrm{m}$. & $\mathcal{O}$ & 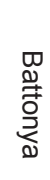 \\
\hline$\stackrel{\circ}{N}$ & $\begin{array}{l}\overrightarrow{0} \\
\stackrel{1}{N}\end{array}$ & $\stackrel{\overrightarrow{\vec{\omega}}}{\vec{\omega}}$ & $\begin{array}{l}\circ \\
\infty\end{array}$ & जि & $\ddot{\omega}$ & 엉 & $\begin{array}{l}\underset{\mathbb{1}}{\mathbf{D}} \\
\frac{0}{0}\end{array}$ & 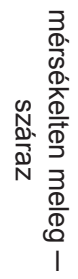 & $\begin{array}{l}\text { Oे } \\
\vec{\perp} \\
\dot{0} \\
\infty \\
0 \\
\tilde{O}\end{array}$ & z & 8 & 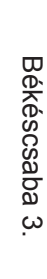 \\
\hline$\stackrel{\circ}{\overrightarrow{0}}$ & $\begin{array}{l}\vec{b} \\
\vec{t} \\
\vec{b}\end{array}$ & $\stackrel{\vec{\omega}}{\vec{\omega}}$ & $\stackrel{0}{0}$ & \pm & $\begin{array}{r}\omega \\
\infty\end{array}$ & ్ & I & 1 & $\begin{array}{l}\text { oे } \\
\text { के } \\
\dot{8} \\
\dot{8}\end{array}$ & $m$ & $\stackrel{\sigma}{\overrightarrow{0}}$ & $\frac{7}{n=}$ \\
\hline
\end{tabular}


5. táblázat. Az Alinda biplicata magasság $(H)$ értékeihez tartozó geográfiai, meteorológiai, vegetációs és statisztikai adatai a különböző gyüjtöhelyeken, különböző idöpontokban

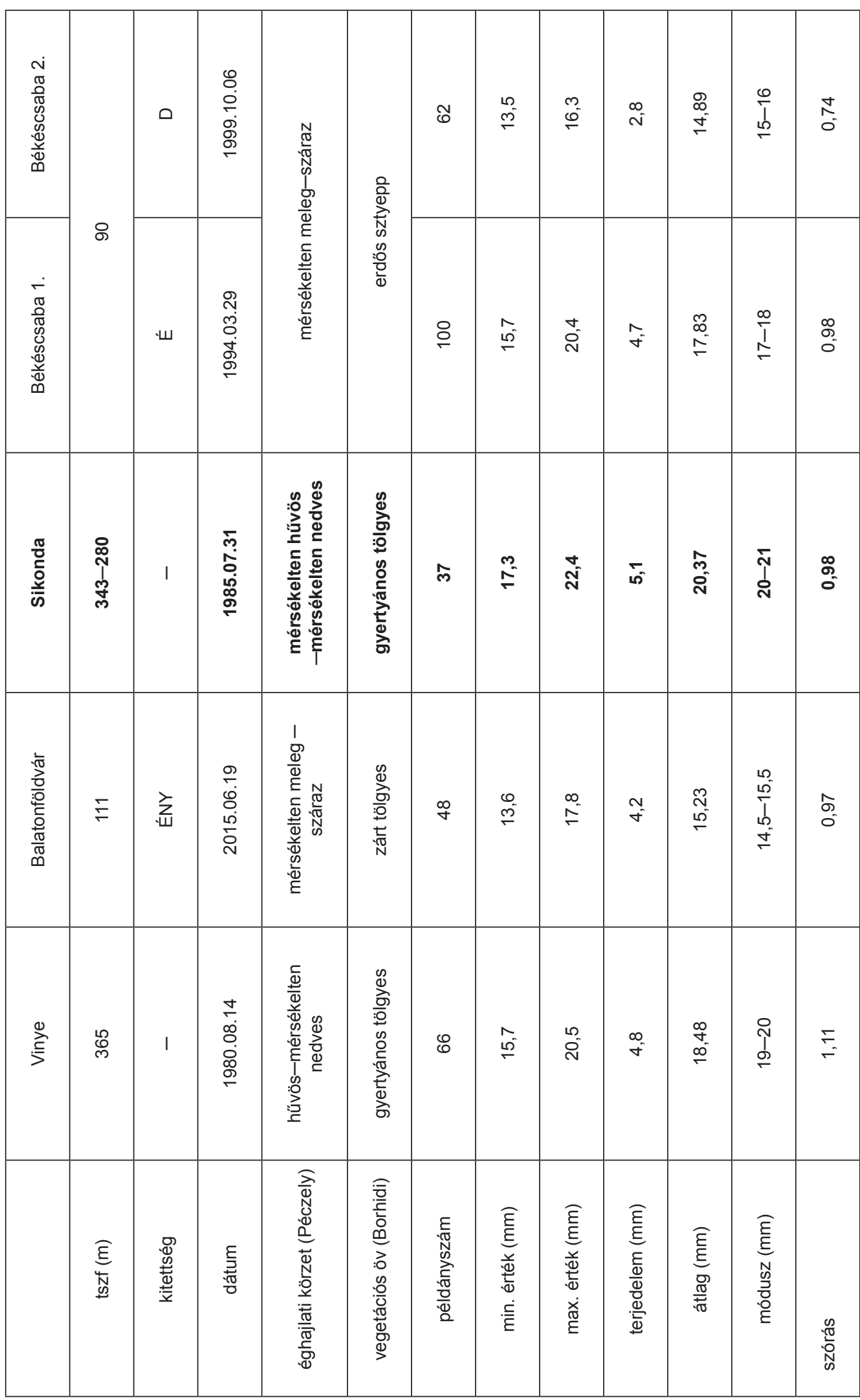


6. táblázat. Az Alindabi biplicata szélesség (W) értékeihez tartozó geográfiai, meteorológiai, vegetációs és statisztikai adatai a különböző gyüjtöhelyeken, különböző időpontokban

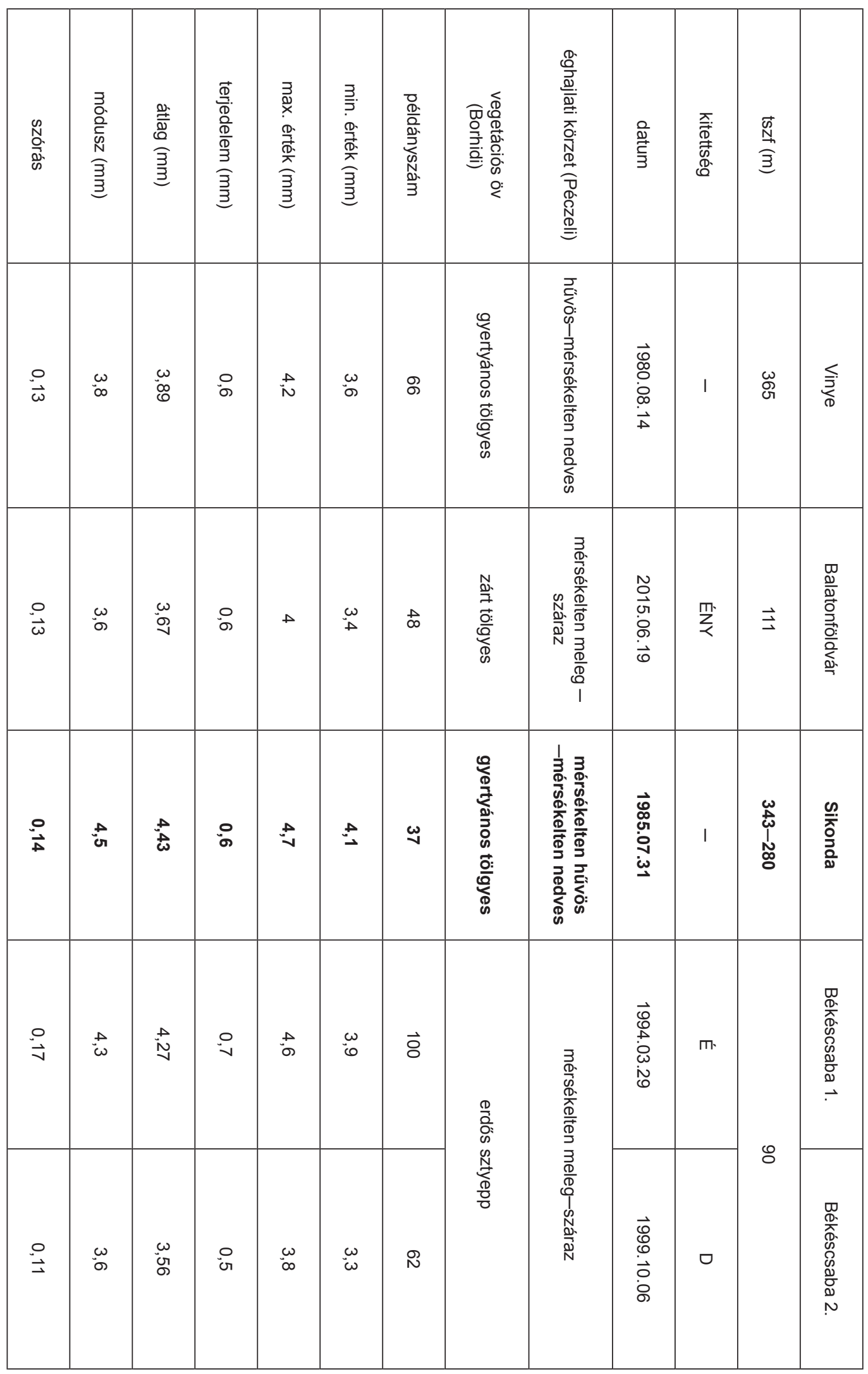


7. táblázat. Az Alinda biplicata nyúltság $(H / W)$ értékeihez tartozó geográfiai, meteorológiai, vegetációs és statisztikai adatai a különböző gyüjtőhelyeken, különböző időpontokban

\begin{tabular}{|c|c|c|c|c|c|c|c|c|c|c|c|c|}
\hline 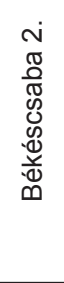 & 0 & 口 & 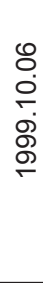 & 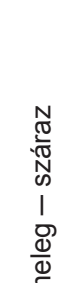 & 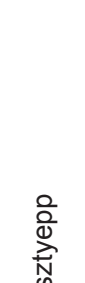 & ชิ & $\hat{m}$ & $\stackrel{0}{\circ}$ & :̊ & 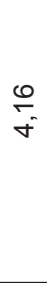 & 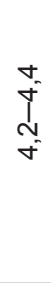 & $\bar{N}$ \\
\hline 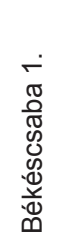 & & שי & 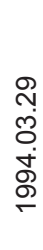 & 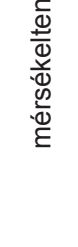 & $\frac{: 0}{\frac{0}{0}}$ & 음 & $\stackrel{\circ}{\circ}$ & $\stackrel{g}{\leftarrow}$ & $\stackrel{m}{=}$ & $\stackrel{M}{=}$ & 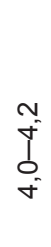 & $\begin{array}{l}\mathbb{N} \\
0\end{array}$ \\
\hline 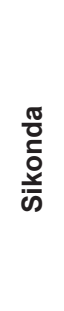 & 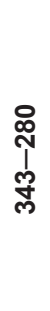 & 1 & 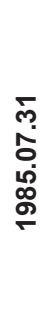 & 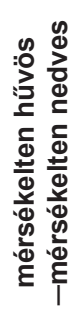 & 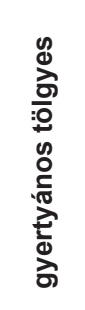 & $\hat{m}$ & $\sigma$ & is & $\stackrel{ \pm}{=}$ & 芦 & $\begin{array}{l}\infty \\
\stackrel{0}{0} \\
0 \\
-\end{array}$ & స̃ \\
\hline 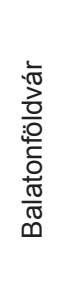 & $E$ & 㐫 & 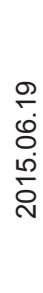 & 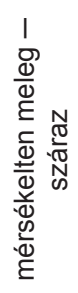 & 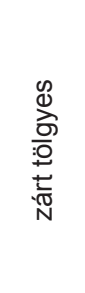 & $\stackrel{\infty}{+}$ & $\hat{m}$ & 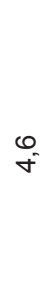 & :̊ & $\underset{\leftarrow}{\stackrel{8}{\circ}}$ & \begin{tabular}{l}
$N$ \\
\multirow{J}{*}{} \\
0 \\
$\sigma^{-}$
\end{tabular} & $\begin{array}{l}\text { Ñ } \\
0\end{array}$ \\
\hline$\stackrel{0}{\stackrel{\sum}{\xi}}$ & 닝 & & 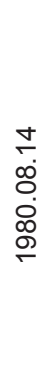 & 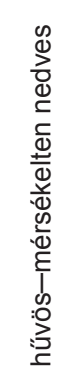 & 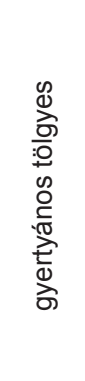 & $\mathscr{8}$ & $\begin{array}{c}\text { m) } \\
\text { (1) }\end{array}$ & ${ }_{6}^{\circ}$ & $\stackrel{\text { م }}{\sim}$ & $\begin{array}{l}\stackrel{8}{8} \\
\&\end{array}$ & \begin{tabular}{l}
$\infty$ \\
\multirow{J}{f}{} \\
\multirow{+}{*}{}
\end{tabular} & స̃ \\
\hline & $\underset{\substack{\mathbb{N} \\
\stackrel{\Phi}{W}}}{\widehat{\xi}}$ & 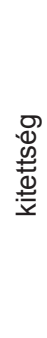 & 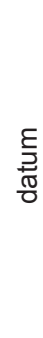 & 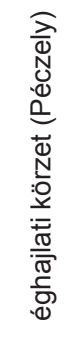 & 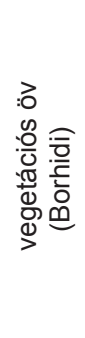 & 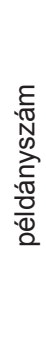 & 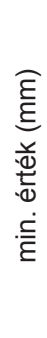 & 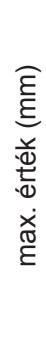 & 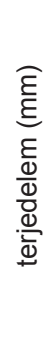 & 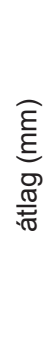 & 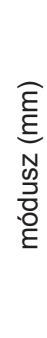 & 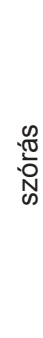 \\
\hline
\end{tabular}




\section{Irodalom}

AGócsY P. 1966: Néhány éticsiga populáció vizsgálata. - Állattani Közlemények, 53: 13-19. Budapest.

ANT H. 1963: Faunistische, ökologische und tiergeographische Untersuchungen zur Verbreitung der Landschnecken in Nordwestdeutschland. - Abhandlungen aus Landesmuseums für Naturkunde zur Münster in Westfalien 1: 1-125. Münster.

BÁBA K. 1982: Eine neue Zoographische Gruppierung der ungarischen Landmollusken und die Wertung des Faunenbildes. - Malacologia 22 (1-2): 441-454. Michigan.

BoRHÍDI A. 2003: Magyarország növénytársulásai. Akadémiai Kiadó. Budapest.

Clauss E. 1979: Eine Population von Helicigona (Drobacia) banatica (Rossmässler, 1938) in Quedlinburg (Gastropoda, Stylommatophora, Helicidae).- Malakologische Abhandlungen 6(6): 85-88.Dresden.

Dомокоs T. 1976: Az Anisus septemgyratus (Rossmässler) és az Anisus leucostoma (Millet) fajok statisztikus vizsgálata I. - Soosiana 4: 57-60. Baja.

Dомокоs T. 1980: A bélmegyeri holocén (rézkori) Unio-félék statisztikus összehasonlítása recens anyaggal. - A Békés Megyei Múzeumok Közleményei 6: 103-115.Békéscsaba.

Dомокоs T. \& FÜкӧн L. 1984: A Granaria frumentum (Draparnaud) héjmorphológiája klimatológiai vizsgálatok tükrében (Gastropoda: Chondrinidae.) - Fol. Hist.-nat. Mus. Matr. ) 9: 91-107

Dомокоs T. 1984: Az Anisus septemgyratus (Rossmässler) és az Anisus leucostoma (Millet) fajok statisztikus vizsgálata II. - Soosiana 12: 11-18. Baja.

Domokos T., LeNNeRT J. \& Sólymos P. 2004: Száraz holtág malakológiai,mikroklimatológiai vizsgálata a Sarkad-Remeteierdőben (Békésmegye), és a Hygromia kovacsi elöfordulási körülményei.- Malakológiai Tájékoztató 22: 87-95. Gyöngyös

Domokos T., Sótymos P. és Kovács Cs.-né 2014: Balaton környéki biotópokból (Tihany, Külsö-Somogy) származó Granaria frumentum (Draparnaud, 1801) héjmorfológiájának klímafüggése (Gastropoda, Chondrinidae). - A Kaposvári Rippl-Rónai Múzeum Közleményei 03: 87-96. Kaposvár.

DövÉNYI Z., Mosolygó L., RAKoncZal J. és TótH J. 1977: Természeti és antropogén folyamatok földrajzi vizsgálata a Kígyósi puszta területen.- Békés megyei Természetvédelmi Évkönyv 2: 43-72. Békéscsaba.

Fehér Z., Varga A., Deli T. \& Domokos T. 2009: Geographic distribution and genital morphology of the genera Lozekia Hudec, 1970 and Kovacsia Nordsieck, 1993 (Molllusca, Gastropoda, Hygromiidae).- Zoosyst.Evol. 85(1): 151-160. Weiheim.

GAÁL I. 1927: Az éghajlat hatása a csigaházra. - Természettudományi Közlöny 59: 466-467. Budapest.

Grossu A. 1981: Gastropoda Romaniae,3, Ed. Litera, Bucureşti.

KAKAS J. 1960: Természetes kritériumok alapján kijelölhető éghajlati körzetek Magyarországon. - Időjárás 6: 328-339. Budapest.

Kerney M. P., Cameron R. A. D. \& Jungbluth J. H. 1983: Die Landschnecken Nord- und Mitteleuropas. P. Parey, HamburgBerlin.

KolESZÁR G. 2014: Térképek. In: http://users.atw.hu/kolegabor/maps.htm

LAIS R.1925: Dr. Hans Kauffman's hinterlassen Schneckensammlung. Schneckenfauna Südbadens und ihrer Beziehungen zum Klima. - Ber. d. Naturf. Ges. Freiburg 25: 1-74.

LožEK V. 1964: Quartärmollusken der Tschechoslowakei. Rozpravy Ú. ú. G.,31. Praha.

LUPU D. 1966: Un fossile vivant de la faune de la Roumani: Chilostoma (Drobacia) maeotica Wenz (Gastropoda-pulmonata). - Musée d'Histoire Naturelle „Grigori Antipa” 6: 31-37. Bucureşti.

NAGY L. 1992: Microclimate types in the southern Bükk. - Abstracta Botanica 16 (2): 87-90. Budapest.
NAGY A. \& SólYmOS P. 2002: Relationship between microclimate and Orthoptera assemblages in different exposures of a dolina. - Articulata 17 (1): 73-84.

NoRdsieck H. 2007: Balea Gray 1824 and Alinda H. \& A. Adams 1855 are separated as genera (Gastropoda: Stylommatophora: Clausiliidae). - Mitteilungen der Deutschen Malakozoologischen Gesellschaft 77/78: 27-30. Frankfurt am Main.

PÉCZely Gy. 1957: Grosswetterlagen in Ungarn. - Országos Meteorológiai Intézet Kisebb Kiadványai 30: 1-51.Budapest.

PÉCZELY GY. 1981: Éghajlattan, Tankönyvkiadó, Budapest.

PÉCZELY GY.: Éghajlati körzetek. In: www.met.hu/éghajlat/Magyarország éghajlata/általános éghajlati jellemzés/általános leírás. Letöltés: 2015. 09. 18.

Peterson Chr. 1921: Das Quotientengesetz.p.55. Kopenhagen.

Petro E. 1963: Az Unio tumidus solidus Zel. és az Unio pictorum balatonicus Küst. határozóbélyegeinek megbízhatósági vizsgálata. - Állattani Közlemények 50: 113-120. Budapest.

ROTARIDES M. 1927: A variábilitásról és tanulmányozásának módszereiröl. Malakozoologiai tanulmány. - Állattani Közlemények 24: 143-163. Budapest.

ROTARIDES M. 1932: Über die Variabilität und die Struktur der Schalenzeichnung bei den Neritinen. - Zoologischer Anzeiger, 100: 257-265. Leipzig.

SHIKoV E. V. \& ZATRAVKIN M. N.1991: The comparative method of taxonomic study of Bivalvia used by Soviet malacologists. - Malakologische Abhandlungen 15 (17): 149-159. Dresden.

Sótymos P. \& Doмokos T. 1999: A possibile connection between macroclimate and shell morphometry of Granaria frumentum (Draparnaud, 1801) (Gastropoda: Chondrinidae) - Malakológiai Tájékoztató, 17: 75-82. Gyöngyös.

SóLYMOS P. \& SüMEGI P. 1999: The shell morpho-thermometer, method and its application in palaeoclimatic reconstruction. - Annales Universitatis Scientiarum Budapestiensis, Sectio - Geologica 32: 137-148. Budapest.

Soós L. 1943: A Kárpát medence Mollusca-faunája. Magyar Tudományos Akadémia, Budapest.

STASEK C. R. 1963:Geometrical form and gnomic growth in bivalved Mollusca. - Journ. Morphol. 112 (3): 215-232. New York.

SÜMEGI P. 1989: A Hajdúság felső pleisztocén fejlődéstörténete finomrétegtani (őslénytani, szedimentológiai, geokémiai) vizsgálatok alapján. - Egyetemi doktori értekezés, KLTE, Debrecen. Manuscriptum.

Szöőr Gy., Balázs É., Cserháti Cs., Dinya Z., Hertelendi E., SÜMEGI P. \& SZANYI J. 1992: Quarter és neogén Molluscahéjak kemotaxonomiai és paleoökológiai elemzése. In: Fáciesanalitikai, paleobiokémiai és paleoökológiai kutatások (szerk.: Szöör Gy.) - MTA Debreceni Akadémiai Bizottság.111182. Debrecen.

THOMPSON, D'A. W. 1917: On growth and form. Cambridge.

THOMPSON, D'A. W. 1942: On growth and form. Cambridge.

THOMPSON, D'A. W. 1959: On growth and form, 2. Cambridge.

WAGNER J. 1929: Zur Variation von Limnaea und biometrische Untersuchungen und Planorbis. - Zoologischer Anzeiger 80: 183-193. Leipzig.

WAGNER M. 1977: Observations on the „ubiquitous” Gastropods of the Pleistocene (Megjegyzések a pleisztocén „ubikvista” csigafajokról). - Földrajzi közlemények 25 (1-3): 212-221. Budapest.

WAGNER M. 1981: A molluszkafauna alapján rekonstruálható éghajlati-ökológiai viszonyok a magyarországi fiatal löszök felső részének képződése idején.(Dunaújváros-Tápiósülyi löszöszlet). - Földrajzi Értesítö 30 (2-3): 315-317. Budapest.

WELTER-SCHULTES F. 2012: European non-marine molluscs, a guide for species identification. Planat Poster Edition, Göttingen. 